\title{
A prospective comparative study on the operative outcomes between monopolar versus bipolar transurethral resection of prostate for benign prostatic hyperplasia: An institutional experience
}

\author{
Vedamurthy Reddy Pogula', Ershad Hussain Galeti ${ }^{2}$, Bhargava Reddy Kanchi V ${ }^{3}$ \\ ${ }^{1}$ Professor and Head, ${ }^{2}$ Senior Resident, ${ }^{3}$ Assistant Professor, Department of Urology, Narayana Medical College, \\ Nellore, Andhra Pradesh, India
}

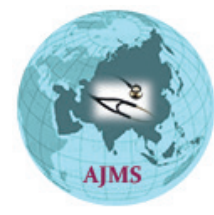

A B S TR A C T

Background: Benign prostatic hyperplasia (BPH) is a common disease in elderly men. Monopolar transurethral resection of prostate (M-TURP) is considered the gold standard for the treatment of bladder outlet obstruction due to BPH. Its modification, bipolar TURP (B-TURP), promises to overcome its most prominent drawbacks, such as bleeding and dilutional hyponatremia. Aims and Objectives: This study aims to study the feasibility, effectiveness, and safety of B-TURP over M-TURP. Materials and Methods: A total of 110 patients with $\mathrm{BPH}$ were prospectively randomly assigned to undergo B-TURP (55) or M-TURP (55). Patient characteristics of the two groups were similar. Hemoglobin was measured preoperatively and postoperatively. IPSS, maximal flow rate, and post-void residual urine volume were assessed preoperatively. Duration of surgery, mean weight of resected tissue, mean irrigation fluid used, mean drop in hemoglobin, mean change in sodium, and mean post-operative irrigation used were also compared. Results: Duration of resection time was significantly shorter in $M$-TURP ( $P=0.0034)$. The mean change in sodium and mean post-operative irrigation used were significantly lower in bipolar group with $\mathrm{P}<0.05$ and 0.0024 , respectively. The mean drop in post-operative hemoglobin concentration $(P=0.0916)$ was statistically insignificant. There was one instance of the transurethral resection (TUR) syndrome in the M-TURP group whereas no TUR syndrome occurred in the B-TURP group. Conclusion: B-TURP and M-TURP are effective and safe techniques for the surgical treatment of BPH. B-TURP definitely reduces the incidence of dilutional hyponatremia and post-operative irrigation use making it a competitor to replace M-TURP as the new gold standard.

Key words: Benign prostatic hyperplasia; Bipolar; Monopolar; Transurethral resection of prostate

\section{Access this article online}

\section{Website:}

http://nepjol.info/index.php/AJMS DOI: 10.3126/ajms.v12i11.38923 E-ISSN: 2091-0576

P-ISSN: 2467-9100

Copyright (c) 2021 Asian Journal of Medical Sciences

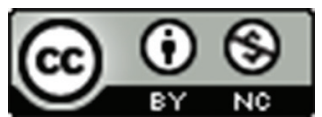

This work is licensed under a Creative Commons Attribution-NonCommercial 4.0 International License.

\section{INTRODUCTION}

Benign prostatic hyperplasia (BPH) is a common disease in elderly men, involving $30 \%$ of men older than 60 years and $40 \%$ of men older than 70 years. ${ }^{1}$ It may lead to different arrays of troublesome symptoms which may not only decrease quality of life but also may increase morbidity and mortality due to its complication. The first-line management for BPH is medical therapy but eventually, surgery is required by $20 \%$ in men. ${ }^{2}$ For many years, the mainstay of treatment for $\mathrm{BPH}$ has been transurethral resection of prostate (TURP) as it is more effective and with less post-operative complications than open prostatectomy. Although TURP is generally considered a safe procedure and has a low mortality rate, there are still some concerns regarding perioperative morbidities, especially hemorrhage, 
dilutional hyponatremia, and transurethral resection (TUR) syndrome. TUR syndrome and hyponatremia are caused using the large amount of nonionic irrigation fluid glycine $(1.5 \%)$ in TURP, which is hypo-osmolar. ${ }^{3,4}$ TURP was traditionally performed using unipolar diathermy which eventually evolved to bipolar TURP (B-TURP) which is a newer modification of TURP. The procedure of bipolar electroresection requires a diathermy generator (200 W and a frequency range of $330-450 \mathrm{kHz}$ and a voltage range of $250-350 \mathrm{~V}$ ) and a cutting loop which is similar to a monopolar loop in shape and should have an active and a return electrode on the same axis. ${ }^{5}$ The basic difference in B-TURP is the use of conductive solution which gets converted into a vapor containing energy charged particles causing tissue dissociation at the molecular level. The charged particles always take the path of low resistance, the saline irrigant, thus controlling treatment site temperatures and lowering the risk of thermal injury to the surrounding tissue. ${ }^{6,7}$ The procedure is completed using a continuous flow resectoscope with saline irrigation reducing the risks of fluid absorption and blood loss. ${ }^{8}$ The B-TURP safety is enhanced by the use of normal saline (NS) which nullifies the incidence of the metabolite toxicities and dilutional hyponatremia." This difference is important at teaching institutions where B-TURP could obviate the increased risk of TUR syndrome due to the prolonged resection times while training the resident surgeons. ' Urologists have observed increased intraoperative visibility during bipolar resection, which may also improve education of the resident. ${ }^{10}$ This study aims to compare monopolar TURP (M-TURP) and B-TURP as a treatment modality for BPH.

\section{Aims and objectives}

This study aims to study the feasibility, effectiveness, and safety of B-TURP over M-TURP.

\section{MATERIALS AND METHODS}

This is a prospective, comparative, longitudinal, singlecenter study done in $110 \mathrm{BPH}$ patients who underwent TURP from June 2017 to May 2020. Inclusion criteria were patients with moderate-to-severe BPH symptoms as per International Prostate Symptom Score (IPSS), maximal urinary flow rate (Qmax) of $<12 \mathrm{ml} / \mathrm{s}$, prostate volume on transabdominal USG exceeding $20 \mathrm{~g}$ with no upper limit, failure of medical therapy (alpha-blockers \pm 5 alphareductase inhibitors), acute urinary retention failing at least one voiding free trial, and upper urinary tract changes due to bladder outlet obstruction due to BPH. Exclusion criteria were neurovesical dysfunction, bladder calculus, carcinoma prostate, previous history of prostatic or urethral surgery, urethral stricture, renal insufficiency, IPSS of $<7$, and previous prostatic surgery (open/transurethral).
After obtaining clearance from the ethical committee, patients were enrolled in the study. Informed consent was obtained from all patients before enrollment into the study.

A detailed history was taken, patients were instructed to complete an IPSS questionnaire and a physical examination including a focused neurological examination was done. The following diagnostic tests were performed: Urine routine and microscopy; urine culture and sensitivity, ultrasound examination of kidney ureter and bladder with prostate volume and post-void residual urine, uroflowmetry, serum prostate-specific antigen (PSA), urodynamic study if neurovesical dysfunction (e.g., diabetes) is suspected to be the cause of voiding dysfunction, hemoglobin $(\mathrm{Hb})$, total leukocyte count and differential leukocyte count, blood urea, serum creatinine, serum sodium, and potassium levels, coagulation profile, blood sugar, ECG, and X-ray chest.

Patients were selected by simple randomization before surgery (1:1) to TURP using $26 \mathrm{~F}$ resectoscope with bipolar ERBE energy source or monopolar (Valleylab) energy source. All patients who underwent surgery were given antibiotic prophylaxis. The procedure was performed in spinal anesthesia. A 26 Fr Karl Storz resectoscope and $1.5 \%$ glycine as the irrigation solution were used for M-TURP. A Valleylab cautery generator was used with the current setting set to 120 Watts cutting and 80 Watts coagulation. B-TURP was performed using 26 Fr Karl Storz resectoscope and $0.9 \%$ NS used as an irrigant, ERBE generator VIO 300 D was used to generate bipolar current. Cautery settings were kept to 6-8 for cutting and 7 for coagulation. Initially, a cystoscopy was done and the findings were noted. The median lobe was resected first in cases where the median lobe was grossly enlarged or protruding into the bladder. Then, either of the lateral lobes was resected. Hemostasis was obtained before resecting the remaining lobe. Then, the anterior lobe was resected. Finally, the apical lobe was resected. A 22 Fr three-way Foley catheter was inserted and irrigation with NS started, traction was kept till the next morning. Orals were started in the evening. Patients were kept on continuous bladder irrigation and the color of the urine was assessed. The catheter was removed on post-operative day 3. Postoperatively, analgesics were given on patients demand. The TURP chips were sent to HPE. All the data were recorded, that is, operative time, intraoperative complications, and amount of irrigant used on immediate post-operative period $\mathrm{Hb} \%$ and serum sodium was measured. TUR syndrome was defined as a serum sodium level of $<125 \mathrm{meq} / \mathrm{L}$ along with cardiological or neurological disturbance (bradycardia, hypertension, visual symptoms, confusion, and disorientation). TUR syndrome was treated by administering frusemide, $3 \% \mathrm{NS}$ slowly, and fluid restriction also. 


\section{Statistical methods}

Statistical testing was conducted with the Statistical Package for the Social Sciences system version Statistical Package for the Social Sciences 20.0. Continuous variables were presented as Mean $\pm \mathrm{SD}$, and categorical variables were presented as absolute numbers and percentages. Statistical t-test of proportion was used to compare the clinical parameter between groups. For all statistical tests, $\mathrm{P}<0.05$ was considered statistically significant.

\section{RESULTS}

Between June 2017 and May 2020, we studied 110 patients with BPH who underwent TURP in the department of urology and randomized them into two equal groups. Among these, 55 cases underwent M-TURP while 55 cases were managed by B-TURP. The following observations were made (Table 1).

\section{Age distribution}

All the demographics and pre-operative clinical parameters were comparable both groups (Table 1). The mean age of our study group was $68.7 \pm 7.1$ years in the B-TURP group and $69.6 \pm 7.2$ years in the monopolar group. Both the groups were matched and the difference between them was statically insignificant $(\mathrm{P}=0.523)$.

\section{IPSS scores}

The mean IPSS scores in the B-TURP group were $21 \pm 2.68$ whereas in the M-TURP group, the mean score was $20 \pm 2.41$. The difference between the groups was statistically not significant $(\mathrm{P}=0.39)$.

\section{Peak flow rates}

The mean Qmax in the bipolar group was 5.8 with a standard deviation of 2.295, whereas in the monopolar group, the average Qmax was 6.1 with a standard deviation of 2.53 . The difference was statistically not significant as $\mathrm{P}=0.48$.

Post-void residual urine in $\mathrm{ml}$ : The mean post-void residual urine in the B-TURP group was $129 \pm 41.69 \mathrm{ml}$ whereas in the M-TURP group, the mean post-void residual urine was $144 \mathrm{ml}$ with a standard deviation of $46.56 \mathrm{ml}$. The difference between the groups was statistically not significant $(\mathrm{P}=0.093)$.

\section{Prostate volume (in cc)}

The mean prostate volume in the B-TURP group was $51 \pm 9.85 \mathrm{cc}$ whereas in the M-TURP group, the mean prostate volume was $47 \mathrm{cc}$ with a standard deviation of 8.91. The difference between the groups was statistically not significant $(\mathrm{P}=0.42)$.

\section{Serum PSA (ng/ml)}

The mean serum PSA in the B-TURP group was $2.5 \pm 0.733 \mathrm{ng} / \mathrm{ml}$ whereas in the M-TURP group, the mean serum PSA was 2.7 with a standard deviation of 0.768 . The difference between the groups was statistically not significant $(\mathrm{P}=0.107)$.

\section{Comorbidities among both groups}

Sixteen patients in the bipolar group and 19 patients in the monopolar group had diabetes mellitus, hypertension was present in 13 in B-TURP group whereas in 12 patients of M-TURP group. Eight patients in B-TURP had coronary artery disease whereas seven patients in the M-TURP group had coronary artery disease.

American society of anesthesiologists (ASA) status of patients

Thirty and 25 patients belonged to ASA Class I in the bipolar and monopolar group, respectively. Fifteen and 17 patients belonged to ASA Class II in the bipolar and monopolar group and only 10 patients were ASA Class III in bipolar and 13 patients belonged to ASA Class III in the monopolar group.

\section{Pre-operative sodium levels ( $\mathrm{mEq} / \mathrm{L}$ )}

The mean sodium levels in the B-TURP group were 138.6 $\pm 3.66 \mathrm{mEq} / \mathrm{L}$ whereas in the M-TURP group, the mean sodium levels were $139.37 \pm 2.798 \mathrm{mEq} / \mathrm{L}$. The difference between the groups was statistically not significant $(\mathrm{P}=0.193)$.

\section{Pre-operative Hb levels ( $\mathrm{g} / \mathrm{dL}$ )}

The mean $\mathrm{Hb}$ levels in the B-TURP group were $13.0 \pm 2.23 \mathrm{~g} / \mathrm{dL}$ whereas in the M-TURP group, the $\mathrm{Hb}$ levels were $13.2 \pm 1.76 \mathrm{~g} / \mathrm{dL}$. The difference between the groups was statistically not significant $(\mathrm{P}=0.59)$.

\section{Weight of tissue resected $(\mathrm{g})$}

The mean weight of resected tissue in the B-TURP group was $26.86 \pm 5.12 \mathrm{~g}$. In the monopolar group, the mean weight of resected tissue was $28.19 \pm 5.02 \mathrm{~g}$, the groups were similar as the difference among the groups was statistically not significant $(\mathrm{P}=0.62)$.

\section{Mean duration of resection (min)}

The mean duration of resection in the bipolar group was $55.71 \pm 13.46 \mathrm{~min}$; the mean duration of resection in the monopolar group was 45.95 min with a standard deviation of 13.9853. The difference among the groups was statistically significant $(\mathrm{P}=0.0034)$.

\section{Mean irrigation fluid used (liters)}

The mean irrigation fluid used in the monopolar group was $21.9 \pm 3.15 \mathrm{~L}$; the mean irrigation fluid used in the 


\begin{tabular}{|c|c|c|c|}
\hline & $\begin{array}{c}\text { Bipolar group } \\
\text { (number of patients) }\end{array}$ & $\begin{array}{c}\text { Monopolar group } \\
\text { (number of patients) }\end{array}$ & P-value \\
\hline \multicolumn{4}{|l|}{ Age group } \\
\hline$<60$ years & 7 & 6 & \multirow[t]{3}{*}{0.523} \\
\hline $60-70$ years & 18 & 21 & \\
\hline$>70$ years & 30 & 28 & \\
\hline \multicolumn{4}{|l|}{ IPSS scores } \\
\hline$<20$ & 20 & 17 & \multirow[t]{2}{*}{0.39} \\
\hline $20-35$ & 35 & 38 & \\
\hline \multicolumn{4}{|l|}{ Peak flow rates } \\
\hline$<7 \mathrm{ml} / \mathrm{s}$ & 35 & 37 & \multirow[t]{2}{*}{0.48} \\
\hline$\geq 7 \mathrm{ml} / \mathrm{s}$ & 20 & 18 & \\
\hline \multicolumn{4}{|l|}{ Post-void residual urine (in ml) } \\
\hline$<150 \mathrm{ml}$ & 37 & 31 & \multirow[t]{2}{*}{0.093} \\
\hline$\geq 150 \mathrm{ml}$ & 18 & 24 & \\
\hline \multicolumn{4}{|l|}{ Prostate volume (in ml) } \\
\hline$<50 \mathrm{ml}$ & 31 & 34 & \multirow[t]{2}{*}{0.42} \\
\hline$\geq 50 \mathrm{ml}$ & 24 & 21 & \\
\hline \multicolumn{4}{|l|}{ Serum PSA (in ng/ml) } \\
\hline$<2 \mathrm{ng} / \mathrm{ml}$ & 15 & 11 & \multirow[t]{2}{*}{0.107} \\
\hline$\geq 2 \mathrm{ng} / \mathrm{ml}$ & 40 & 44 & \\
\hline \multicolumn{4}{|l|}{ Comorbidities } \\
\hline Diabetes mellitus & $16(29 \%)$ & $19(34.5 \%)$ & \multirow[t]{3}{*}{---- } \\
\hline Hypertension & $13(23.6 \%)$ & $12(21.8 \%)$ & \\
\hline Coronary artery disease & $8(14.5 \%)$ & $7(12.7 \%)$ & \\
\hline \multicolumn{4}{|l|}{ ASA status } \\
\hline ASA I & 30 & 25 & \multirow[t]{3}{*}{----} \\
\hline ASA II & 15 & 17 & \\
\hline ASA III & 10 & 13 & \\
\hline Mean sodium levels (mEq/L) & 138.6 & 139.4 & 0.193 \\
\hline Mean $\mathrm{Hb}$ in $\mathrm{g} / \mathrm{dL}$ & 13.04 & 13.24 & 0.598 \\
\hline Mean weight of resected tissue $(\mathrm{g})$ & 26.86 & 28.19 & 0.626 \\
\hline Mean duration of resection (min) & 55.7 & 45.9 & 0.0034 \\
\hline Mean irrigation fluid used (liter) & 21.9 & 24.0 & 0.59 \\
\hline Mean change in sodium (mEq/L) & -1.8 & -5.1 & $P<0.05$ \\
\hline Mean post-operative irrigation used (liters) & 14.3 & 18.3 & 0.0024 \\
\hline Mean fall in $\mathrm{Hb}(\mathrm{g} / \mathrm{dL})$ & 1.3 & 1.6 & 0.0916 \\
\hline
\end{tabular}

TRUP: Transurethral resection of prostate, IPSS: International Prostate Symptom Score, PSA: Prostate-specific antigen, ASA: American Society of Anesthesiologists, Hb: Hemoglobin

bipolar group was $24 \mathrm{~L}$ with a standard deviation of 3.70 . The difference among the groups was statistically not significant $(\mathrm{P}=0.59)$.

\section{Change in sodium}

The mean fall in sodium in the B-TURP group was $1.82 .43 \mathrm{mEq} / \mathrm{L}$, whereas the mean fall in the sodium in the monopolar group was $5.1 \pm 2.60 \mathrm{mEq} / \mathrm{L}$. The difference among the groups was statistically significant $(\mathrm{P}<0.05)$.

Mean post-operative irrigation used (liters)

The mean post-operative irrigation used in the B-TURP group was $14.3 \pm 5.978 \mathrm{~L}$ whereas in the M-TURP group, it was $18.3 \pm 4.867 \mathrm{~L}$. The difference among the groups was statistically significant $(\mathrm{P}=0.00246)$.

Mean fall in $\mathrm{Hb}(\mathrm{g} / \mathrm{dL})$

The mean fall in $\mathrm{Hb}$ in the B-TURP group was $1.3 \pm 0.521 \mathrm{~g} / \mathrm{dL}$ whereas in the M-TURP group, the mean fall in $\mathrm{Hb}$ was $1.6 \pm 0.4750 \mathrm{~g} / \mathrm{dL}$. The difference was statistically not significant $(\mathrm{P}=0.0916)$.

\section{DISCUSSION}

The incidence of benign prostatic enlargement and related lower urinary tract symptoms (LUTS) in men increases with age, and about $25 \%$ of men estimated to have received treatment for LUTS by 80 years of age. ${ }^{11}$ Despite the advances in medical therapy, a significant proportion of patients require surgical intervention, these vary from minimally invasive surgical treatments to open prostatectomy. The most common and the gold standard of these procedures is TURP, achieving long-lasting functional outcomes. ${ }^{12}$ TURP has been there in the urologist armamentarium for a long and has withstood the test of time as it is advantageous in removing the extensive tissue in a very short time and its ability to do so within anatomical and surgical landmarks. TURP is regularly performed by 
monopolar diathermy, which involves an electrical flow current from an active electrode to the prostate and through the body and exits through a return electrode pad placed on the skin. M-TURP requires the irrigation fluids, which are iso-osmolar and molecularly inert, non-conductive and optically clear is required, for example, glycine, sorbitol, or mannitol solutions. The use of glycine which is relatively hypo-osmolar places the patient at risk of dilutional hyponatremia and TUR syndrome, which is indicated by metabolic abnormalities, cardiovascular problems, and neurological irregularities and is associated with a risk of mortality in up to $40 \%$ of the patients. ${ }^{13}$ In contrary to M-TURP, B-TURP uses a current that travels through the loop and prostate tissue but not through the patient's body, thus enabling the use of isotonic solutions like $0.9 \%$ NS. Thus, reducing some of the problems associated with M-TURP, such as TUR syndrome.

In our study, we studied the patients undergoing TURP and compared the effectiveness of B-TURP and M-TURP in the management of BPH. In our study, the demographics were neck to neck with other studies, the mean age in the monopolar group was $69.6 \pm 7.2$ years, and in the bipolar group, it was $68.7 \pm 7.1$ years. The results were similar to the other studies as BPH usually affect older men. The difference among the groups was statistically not significant $(\mathrm{P}=0.523)$. The age difference was similar to those observed by Abascal Junquera et al., ${ }^{14}$ where the age in the monopolar group was 67.3 years, and in the bipolar group, it was 69.5 years. The mean ages observed by Ho and Cheng et al., ${ }^{15}$ where the mean age of the monopolar group was 66.5 years whereas in the bipolar group, it was 66.6 years.

The mean IPSS score in the B-TURP group was $21 \pm 2.68$ whereas in the M-TURP group was 20. The difference between the groups was statistically not significant with $\mathrm{P}=0.390$. The results were similar to those found by Fagerström et al., ${ }^{16}$ where the mean IPSS in the monopolar group was 20.4 and in the bipolar group, it was 21.7. The mean IPSS in our study was lesser than that of Singhania et al., ${ }^{13}$ where the mean IPSS in the monopolar group was 23.43 and 24.07 in the bipolar group.

The mean Qmax in the bipolar group was $5.8 \pm 2.295 \mathrm{ml} / \mathrm{s}$, whereas in the monopolar group, the average Qmax was $6.1 \pm 2.295 \mathrm{ml} / \mathrm{s}$. These findings were similar to that of Singh et al., ${ }^{17}$ where the mean Qmax in the monopolar group was $5.1 \mathrm{ml} / \mathrm{s}$ and was $5.8 \mathrm{ml} / \mathrm{s}$ in bipolar group. Erturhan et al., ${ }^{18}$ on other hand had, greater Q max values in both the monopolar and bipolar groups, in their study, the mean Qmax was $9.2 \mathrm{ml} / \mathrm{s}$ in the monopolar group whereas the mean Qmax in the bipolar group was found to be $10.9 \mathrm{ml} / \mathrm{s}$. The reason for lower mean Qmax in our study was partly due to the fact that Qmax of $<12 \mathrm{ml} / \mathrm{s}$ was taken as an inclusion criterion for the study.

The mean post-void residual urine in the B-TURP group of patients was $129 \pm 41.69 \mathrm{ml}$ whereas that of the M-TURP group was $144 \pm 46.56 \mathrm{ml}$. The difference between the groups was statistically not significant $(\mathrm{P}=0.093)$. Our results were similar to those of Singh et al., ${ }^{17}$ where the patients in the monopolar group had a post-void residue (PVR) of $136 \pm 52 \mathrm{ml}$ and in the bipolar group, it was $124 \pm 58 \mathrm{ml}$. In the study conducted by Ho et al. ${ }^{15} \mathrm{PVR}$ in the monopolar group was $147 \mathrm{ml}$, whereas in the bipolar group, it was $182.0 \mathrm{ml}$ [Table 2].

The mean prostate volume in the B-TURP group was $51 \pm 9.85 \mathrm{cc}$ whereas, in the M-TURP group, it was $47 \pm 8.91$ cc. The difference between the two groups was statistically not significant $(\mathrm{P}=0.042)$. In the study conducted by Chen et al., ${ }^{19}$ the patients undergoing B-TURP had a mean prostate size of $49.1 \pm 20.5 \mathrm{ml}$ while those undergoing M-TURP had a prostate volume of $47.3 \pm 16.9$ and the difference was not significant $\mathrm{P}=0.335$. According to other studies conducted and reported in the literature, the prostate size varied from 42 to $82 \mathrm{ml}$ for the monopolar group and for the bipolar group, it varied from $39 \mathrm{ml}$ to $82 \mathrm{ml}^{2,8,13,17,20}$

The mean serum PSA in the B-TURP group was $2.5 \pm 0.733 \mathrm{ng} / \mathrm{ml}$ whereas, in the M-TURP group, the mean serum PSA was $2.7 \pm 0.768$. The difference observed between the groups was statistically not significant $\mathrm{P}=0.107$. Going through the literature, Yoon et al., ${ }^{2}$ reported the mean PSA of men undergoing B-TURP to be $2.89 \pm 1.34 \mathrm{ng} / \mathrm{ml}$ whereas the mean PSA of men undergoing M-TURP was $2.72 \pm 0.91 \mathrm{ng} / \mathrm{ml} ; \mathrm{P}=0.27$. Our results are similar to Singh et al., ${ }^{12}$ where the mean PSA in the bipolar group was $2.75 \mathrm{ng} / \mathrm{ml}$ and in the monopolar group, it was $3.2 \mathrm{ng} / \mathrm{ml}$.

The mean weight of resected tissue in patients in the B-TURP group was $26.86 \pm 5.12 \mathrm{~g}$. In the monopolar group of patients, the mean weight of resected tissue was $28.19 \mathrm{~g}$ with a standard deviation of 5.02 , the groups were similar as the difference among the groups was statistically not significant $\mathrm{P}=0.6267$. The mean resected weight was higher in our study when compared to Singh et al., ${ }^{17}$ where the mean resected tissue in the bipolar group was $24 \mathrm{~g}$ and in the monopolar group, it was $27.6 \mathrm{~g}$. Our results are similar to Seckiner et al. ${ }^{21}$ where the mean resected tissue in the bipolar group was $36.6 \mathrm{~g}$ and in the monopolar group, it was $31.9 \mathrm{~g}$. Ho et al., ${ }^{15}$ in his study, observed that the mean resected tissue in the bipolar group was $29.8 \mathrm{~g}$ and in the patients of the monopolar group, it was $30.6 \mathrm{~g}$. These results are also comparable to our results. 
The mean duration of resection in patients of the bipolar group was $55.71 \pm 13.46 \mathrm{~min}$, whereas the mean duration of resection in the monopolar group was 45.95 min with a standard deviation of 13.98. The difference among the groups was statistically significant $\mathrm{P}=0.0034$. Our findings are similar to Seckiner et al., ${ }^{21}$ who in his study noted that the time for resection in B-TURP was $52.9 \mathrm{~min}$ and in M-TURP, it was $52.9 \mathrm{~min}$. Hon et al., ${ }^{20}$ observed that the time taken for B-TURP was $59.0 \mathrm{~min}$ and for M-TURP, it was $58.0 \mathrm{~min}$ [Table 3].

The mean irrigation fluid that was used in the monopolar group was $21.9 \mathrm{~L}$ with a standard deviation of 3.15 , the mean irrigation fluid that was used in the bipolar group was $24 \pm 3.70 \mathrm{~L}$. The difference among the groups was statistically not significant $(\mathrm{P}=0.59)$. The results are similar to Singh et al., ${ }^{17}$ who used 19.6 L of irrigation fluid in patients of the bipolar group and $17.3 \mathrm{~L}$ of irrigation fluid in the monopolar group [Table 4].

The mean fall in sodium levels in the B-TURP group was $1.8 \pm 2.43 \mathrm{mEq} / \mathrm{L}$, whereas the mean fall in the sodium level in the monopolar group was $5.1 \mathrm{mEq} / \mathrm{L}$ with a standard deviation of 2.60. The difference among the groups was statistically significant $\mathrm{P}<0.05$. Singh et al., ${ }^{17}$ had similar observations in their study and they found that the change in serum sodium concentration was significantly greater in the monopolar resection group. Similar results were obtained in the study done by Singhania et al., ${ }^{13}$ who observed that the fall in sodium level in the bipolar group was lower than that in the monopolar group. They observed that while comparing the groups, the monopolar glycine group showed a greater decline in serum sodium level $(4.12 \mathrm{meq} / \mathrm{L})$ as compared to the bipolar saline group $(1.3 \mathrm{meq} / \mathrm{L})$. However, this was not statistically significant between the groups $(\mathrm{P}=0.93)$. Michielsen et al., ${ }^{22}$ in their study also revealed similar observations, they found that in the conventional M-TURP group, serum sodium declined by $2.5 \mathrm{mmol} / \mathrm{l}$. This was statistically significantly different $(\mathrm{P}=0.001)$ from the drop of $1.5 \mathrm{mmol} / \mathrm{l}$ in the bipolar group of patients.

In our study, only one patient from the monopolar group developed TUR syndrome and none in the bipolar group. His sodium levels dropped to $110 \mathrm{mEq} / \mathrm{L}$, the patient developed ECG changes followed by generalized seizures, the procedure was abandoned and the patient was managed in ICU overnight, intubated on mechanical ventilation, his sodium levels were corrected gradually and extubated on the $1^{\text {st }}$ post-operative day, he was discharged on the $4^{\text {th }}$ post-operative day with the catheter in situ with no neurological deficit.

The mean post-operative irrigation fluids used in the B-TURP group were $14.3 \mathrm{~L}$ with a standard deviation

\begin{tabular}{lcc}
\multicolumn{3}{c}{ Table 2: Comparison of mean resected tissue } \\
\hline & Bipolar (g) & Monopolar (g) \\
\hline Present study & 26.8 & 28.1 \\
Singh et al., ${ }^{17}$ & 24.0 & 27.6 \\
Seckiner et al., $^{21}$ & 36.6 & 31.9 \\
Ho et al., ${ }^{15}$ & 29.8 & 30.6 \\
\hline
\end{tabular}

\begin{tabular}{|c|c|c|}
\hline & Bipolar (min) & Monopolar (min) \\
\hline Present study & 55.7 & 45.95 \\
\hline Seckiner et al., ${ }^{21}$ & 52.9 & 52.9 \\
\hline Hon et al. ${ }^{20}$ & 59.0 & 58.0 \\
\hline
\end{tabular}

\begin{tabular}{|c|c|c|c|}
\hline & $\begin{array}{l}\text { Bipolar } \\
\text { (mEq/L) }\end{array}$ & Monopolar (mEq/L) & $P$ value \\
\hline Present study & $1.8 \pm 2.43$ & $5.1 \pm 2.6$ & $<0.005$ \\
\hline Singh et al., ${ }^{17}$ & 1.2 & 4.6 & $<0.001$ \\
\hline Chen et al., ${ }^{19}$ & $6.9 \pm 0.7$ & $14.8 \pm 1.8$ & 0.001 \\
\hline Singhania et al., ${ }^{13}$ & 1.3 & 4.12 & 0.2 \\
\hline
\end{tabular}

of 5.978 whereas in the M-TURP group, it was $18.3 \mathrm{~L}$ with a standard deviation of 4.867 . The difference among the groups was statistically significant $P=0.0024$. Singh et al., ${ }^{17}$ observed that the post-operative irrigation used in the bipolar groups was $9.9 \mathrm{~L}$ with a standard deviation of 6.2 , whereas in the monopolar group, it was $9.8 \mathrm{~L}$ with a standard deviation of 3.4 , the difference among the groups was statistically not significant $\mathrm{P}=0.405$. Xie et al., ${ }^{23}$ in their study reported a post-operative irrigation time of $24.45 \mathrm{~h}$ in the M-TURP group and $15.84 \mathrm{~h}$ in the B-TURP group.

The mean fall in $\mathrm{Hb}$ in the B-TURP group was $1.3 \mathrm{~g} /$ $\mathrm{dL}$ with the standard deviation of 0.5210 whereas in the M-TURP group, the mean fall in $\mathrm{Hb}$ was $1.6 \mathrm{~g} / \mathrm{dL}$ with a standard deviation of 0.4750 . The difference among the groups was statistically not significant $\mathrm{P}=0.091$. The international multicenter randomized control trial also reported a statistically insignificant difference in the $\mathrm{Hb}$ drop after monopolar prostatectomy and bipolar prostatectomy $\mathrm{P}=0.548 .{ }^{19}$ Giulianelli et al. ${ }^{24}$ reported a drop from mean $\mathrm{Hb}$ of $14.5 \mathrm{~g} / \mathrm{dL}$ to $10.4 \mathrm{~g} / \mathrm{dL}$ in the monopolar group whereas in the bipolar group, the mean $\mathrm{Hb}$ drop was from $14.8 \mathrm{~g} / \mathrm{dL}$ to $13.6 \mathrm{~g} / \mathrm{dL}$, however, authors did not mention if it was statistically significant. None of our patients in the bipolar or the M-TURP group required blood transfusion. It is hypothesized that bipolar electrocautery is more efficient in controlling bleeding according to the ex vivo experiments conducted by WendtNordahl ${ }^{25}$ than a monopolar resectoscope. 


\section{CONCLUSION}

B-TURP is a feasible and effective method for BPH MANAGEMENT with the added advantages of decreased incidence of hyponatremia and TUR syndrome compared to M-TURP, thus reducing the adverse post-operative outcomes.

\section{ACKNOWLEDGMENT}

We extend their sincere thanks to all the patients who participated in the study.

\section{REFERENCES}

1. Boyle P, Robertson C, Mazzetta C, Keech M, Hobbs FD, Fourcade R, et al. The prevalence of lower urinary tract symptoms in men and women in four centres. The UrEpik study. BJU Int. 2003;92(4):409-414.

https://doi.org/10.1046/j.1464-410x.2003.04369.x

2. Yoon CJ, Kim JY, Moon KH, Jung HC and Park TC. Transurethral resection of the prostate with a bipolar tissue management system compared to conventional monopolar resectoscope: One-year outcome. Yonsei Med J. 2006;47(5):715-720.

https://doi.org/10.3349/ymj.2006.47.5.715

3. Uchida T, Ohori M, Soh S, Sato T, Iwamura M, Ao T, et al. Factors influencing morbidity in patients undergoing transurethral resection of the prostate. Urology. 1999;53(1):98-105.

https://doi.org/10.1016/s0090-4295(98)00524-x

4. Horninger W, Unterlechner $H$, Strasser $H$, Bartsch G. Transurethral prostatectomy: Mortality and morbidity. Prostate. 1996;28(3):195-200.

https://doi.org/10.1002/(sici)1097-0045(199603)28:3<195::aidpros6>3.0.co;2-e

5. Sio M, Autorino R, Quarto G, Damiano R, Perdonà S, Lorenzo G, et al. Gyrus bipolar versus standard monopolar transurethral resection of the prostate: A randomized prospective trial. Urology. 2006;67(1):69-72.

https://doi.org/10.1016/j.urology.2005.07.033

6. Eaton $\mathrm{AC}$ and Francis RN. The provision of transurethral prostatectomy on a day-case basis using bipolar plasma kinetic technology. BJU Int. 2002;89(6):534-537.

https://doi.org/10.1046/j.1464-410x.2002.02673.x

7. Botto $H$, Lebret $T$, Barré $P$, Orsoni JL, Hervé JM and Lugagne PM. Electrovaporization of the prostate with the Gyrus device. J Endourol. 2001;15(3):313-316.

https://doi.org/10.1089/089277901750161917

8. Starkman JS and Santucci RA. Comparison of bipolar transurethral resection of the prostate with standard transurethral prostatectomy: Shorter stay, earlier catheter removal and fewer complications. BJU Int. 2005;95(1):69-71.

https://doi.org/10.1111/j.1464-410x.2005.05253.x

9. Gilleran JP, Thaly RK and Chernoff AM. Rapid communication: Bipolar PlasmaKinetic transurethral resection of the prostate: Reliable training vehicle for today's urology residents. J Endourol. 2006;20(9):683-687.

https://doi.org/10.1089/end.2006.20.683

10. Tefekli A, Muslumanoglu AY, Baykal M, Binbay M, Tas A and Altunrende F. A hybrid technique using bipolar energy in transurethral prostate surgery: A prospective, randomized comparison. J Urol. 2005;174(4 Part 1):1339-1343.

https://doi.org/10.1097/01.ju.0000173075.62504.73

11. NICE Guidance Prostate artery embolisation for lower urinary tract symptoms caused by benign prostatic hyperplasia: ( $)$ NICE (2018) Prostate artery embolisation for lower urinary tract symptoms caused by benign prostatic hyperplasia: (C) NICE (2018) Prostate artery embolisation for lower urinary tract symptoms caused by benign prostatic hyperplasia. BJU Int. 2018;122(1):11-12.

https://doi.org/10.1111/bju.14404

12. Lourenco T, Pickard R, Vale L, GrantA, Fraser C and MacLennan G. Benign prostatic enlargement team. BMJ. 2008;337(9):1662. https://doi.org/10.1136/bmj.a1662

13. Singhania $P$, Nandini $D$, Sarita F, Hemant $P$ and Hemalata I. Transurethral resection of prostate: A comparison of standard monopolar versus bipolar saline resection. Int Braz J Urol. 2010;36(2):183-189.

https://doi.org/10.1590/s1677-55382010000200008

14. Abascal Junquera JM, Cecchini Rosell L, Salvador Lacambra C, Martos Calvo R, Celma Domenech A, Morote Robles J. Transurethral resection of the prostate bipolar vs monopolar: perioperative analysis of the results. Actas Urol Esp.2006;30 (7): 661-6. https://doi.org/10.1016/s0210-4806(06)73515-x

15. Ho HS and Cheng CW. Bipolar transurethral resection of prostate: A new reference standard? Curr Opin Urol. 2008;18(1):50-55.

16. Fagerström $T$, Nyman $C R$ and Hahn RG. Bipolar transurethral resection of the prostate causes less bleeding than the monopolar technique: A single-centre randomized trial of 202 patients. BJU Int. 2010;105(11):1560-1564.

https://doi.org/10.1111/j.1464-410x.2009.09052.x

17. Singh $H$, Desai MR, Shrivastav $P$ and Vani K. Bipolar versus monopolar transurethral resection of prostate: Randomized controlled study. J Endourol. 2005;19(3):333-338.

https://doi.org/10.1089/end.2005.19.333

18. Erturhan S, Erbagci A, Seckiner I, Yagci $F$ and Ustun A. Plasmakinetic resection of the prostate versus standard transurethral resection of the prostate: A prospective randomized trial with 1-year follow-up. Prostate Cancer Prostatic Dis. 2007;10(1):97-100.

https://doi.org/10.1038/sj.pcan.4500907

19. Chen Q, Zhang L, Liu YJ, Lu JD and Wang GM. Bipolar transurethral resection in saline system versus traditional monopolar resection system in treating large-volume benign prostatic hyperplasia. Urol Int. 2009;83(1):55-59. https://doi.org/10.1159/000224869

20. Hon NHY, Brathwaite D, Hussain Z, Ghiblawi S, Brace H, Hayne D, et al. A prospective, randomized trial comparing conventional transurethral prostate resection with PlasmaKinetic vaporization of the prostate: Physiological changes, early complications and long-term followup. J Urol. 2006;176(1):205-209.

https://doi.org/10.1016/s0022-5347(06)00492-7

21. Seckiner I, Yesilli C, Akduman B, Altan $\mathrm{K}$ and Mungan NA. A prospective randomized study for comparing bipolar plasmakinetic resection of the prostate with standard TURP. Urol Int. 2006;76(2):139-143. https://doi.org/10.1159/000090877

22. Michielsen DP, Coomans D, Braeckman JG and Umbrain V. Bipolar transurethral resection in saline: The solution to avoid hyponatraemia and transurethral resection syndrome. Scand J Urol Nephrol. 2010;44(4):228-235. 
https://doi.org/10.3109/00365591003720275

23. Xie CY, Zhu GB, Wang XH and Liu XB. Five-year follow-up results of a randomized controlled trial comparing bipolar plasmakinetic and monopolar transurethral resection of the prostate. Yonsei Med J. 2012;53(4):734-741.

https://doi.org/10.3349/ymj.2012.53.4.734

24. Giulianelli R, Albanesi L, Attisani F, Gentile BC, Vincenti G, Pisanti $F$, et al. Comparative randomized study on the efficaciousness of endoscopic bipolar prostate resection versus monopolar resection technique. 3 year follow-up. Arch Ital Urol Androl. 2013;85(2):86-91.

https://doi.org/10.4081/aiua.2013.2.86

25. Wendt-Nordahl G, Häcker A, Reich O, Djavan B, Alken P, Michel MS. The Vista system: a new bipolar resection device for endourological procedures:comparison with conventional resectoscope. Eur Urol. 2004 Nov;46(5):586-90.

\section{Authors Contribution:}

VMR - Concept and design of the study; prepared first draft of manuscript; and interpreted the results; EHG - Reviewed the literature and manuscript preparation, statistically analyzed and interpreted; BRKV - Coordination, review of literature, and revision of the manuscript.

\section{Work attributed to:}

Narayana Medical College, Nellore, Andhra Pradesh, India

\section{Orcid ID:}

Dr. Vedamurthy Reddy Pogula - (1) http://orcid.org/0000-0001-7778-2950

Dr. Ershad Hussain Galeti - (1) http://orcid.org/0000-0003-3857-5400

Source of Support: Nil, Conflicts of Interest: None declared. 